\title{
Sociological Problem and Social Problem: Contributions to a Discussion
}

\author{
Sandro Serpa ${ }^{1,2, *}$, Carlos Miguel Ferreira ${ }^{2,3,4}$ \\ ${ }^{1}$ Department of Sociology, Faculty of Social and Human Sciences, University of the Azores, Portugal \\ ${ }^{2}$ Interdisciplinary Centre of Social Sciences-CICS.UAc/CICS.NOVA.UAc, Portugal \\ ${ }^{3}$ Estoril Higher Institute for Tourism and Hotel Studies, Portugal \\ ${ }^{4}$ Polytechnic Institute of Castelo Branco, Portugal
}

Copyright $\bigcirc 2018$ by authors, all rights reserved. Authors agree that this article remains permanently open access under the terms of the Creative Commons Attribution License 4.0 International License

\begin{abstract}
The creation of a scientific object constructed by a theoretical framework that shapes the view of Sociology as a science and that translates into a sociological problem is one of the vital stages of sociological knowledge. However, both literature and our experience in teaching Sociology in programmes that train future sociologists, as well as in other training programmes, demonstrate that there is often some confusion and difficulty in distinguishing sociological problem from social problem. In this reflection, which is based on a perspective from Portugal - where the authors teach and carry out research -, necessarily open to debate considering all the risks that this kind of analysis entails, we aim to put forward our stance on the topic of the relationship between sociological problem and social problem.
\end{abstract}

Keywords Sociological Problem, Social Problem, Sociology, Scientific Object, Sociological Object, Scientific Knowledge, Reflexivity

\section{Introduction}

The creation of a scientific object constructed by a theoretical framework that shapes the view of Sociology as a science and that translates into a sociological problem is one of the vital stages of sociological knowledge. However, both literature and our experience in teaching Sociology in programmes that train future sociologists, as well as in other training programmes, demonstrate that there is often some confusion and difficulty in distinguishing sociological problem from social problem (Ferreira \& Serpa, 2017; Santos, 1999). This paper aims to present some contributions to the clarification of the differences and relations between social problem and sociological problem.

To fulfil this purpose, we offer a concise clarification of our stance on an extremely ambitious and broad subject, in which we address issues related to Sociology as scientific knowledge and the relationship of Sociology with other social sciences. The paper ends with some insights on the importance of reflexivity, at several levels, in the formulation of the sociological problem and its relationship with the social problem.

\section{Sociology and sociological problem}

\subsection{Sociology}

To carry out research is, in truth, to create or confirm scientific knowledge. Scientific knowledge may be considered as a set of verified and verifiable knowledge, obtained through a systematic process and demonstrated in a rigorous and controlled way. This rigour and control must be present both in the process (in the execution of a research) and in the product of a research (in its final result, such as, for instance, an article, a book, a report or a presentation, among others) (Ferreira \& Serpa, 2017).

This scientific knowledge results from a process of abstraction and construction (Silva, 1986; Au, 2017) of a look upon reality. This procedure entails a rupture with common sense and everyday language (Santos, 1999), that is, all types of knowledge neither verified nor verifiable, with little empirical reasoning and normative in nature, and that cannot be proved, contrary to scientific knowledge (Silva, 1986).

In its specific look upon reality, each science uses an object of study, theories, methods and a body of knowledge:

Each scientific field thus proposes an articulated set of questions - its theoretical problematic - that demarcates zones of visibility. This problematic, a starting point, at each moment, of the research that is carried out, defines and welcomes research problems, 
for which answers are sought. The means of obtaining them, in turn, lie in the whole set of substantive conceptual availabilities - the theories in a narrow sense - that the discipline has been forging, as well as in technical instruments for collecting and processing information organised by methods, as provisional codification of the critical research paths (Almeida $\&$ Pinto, 1986, p. 63).

Specifically, given that the social world is multidimensional and complex - total social phenomenon (Marcel Mauss) -, social sciences have a complementary nature (Silva, 1986), and, starting from the same real object or phenomenon, each science constructs different objects of analysis according to their aforementioned specific reading codes, through a directed selection of their stance, which is not immune to the social context itself (Nunes, 2005; Santos, 1999; Silva, 1986).

This is also true with Sociology as a science that studies the (dis)order of the social world, and that deals with interactions, what results from interaction and has implications in this interaction between human beings, such as objects, practices, representations and values, inserting them into their social context (Ferreira \& Serpa, 2017). As sustained by Pires (2012), social predictability and order are critical in social life:

[...] when it is acknowledged that there is something we call society, it is because it is acknowledged that social life is not chaotic but rather ordered, that there are regularities in observable behaviours and interactions, that the reactions of others to our actions are, in general, predictable. In other words, we acknowledge society in the ordering of human life ( $\mathrm{p}$. 31).

These shared expectations exist regardless of the level of sociological analysis (micro, meso or macrosocial) (Ferreira \& Serpa, 2017; Serpa, 2018), thanks to the socialisation process that, through the learning of the culture of a given social environment, translated in ways of acting, thinking and feeling, allows the attainment of common expectations in social life, but always with some relative autonomy of the individual (Cherkaoui, 1990; Serpa, 2018). Socialisation is dynamic, not deterministic and is never completed: "One socialises at the same time that one is socialised, one builds oneself to the extent that one is built by others" (Javeau, 1998, p. 167).

Even though it is a multi-paradigmatic science (Almeida, 1995; Ferreira \& Serpa, 2017; Javeau, 1998; Serpa, 2018; Mora, 2015), Sociology has always an empirical dimension in its quest to explain the social through the social (Durkheim, 1895/1998; Javeau, 1998; Paiva, 2014).

In this quest to explain the social through the social, Sociology employs

[...] a set of systematised and accrued knowledge; a set of concepts that define parts of the real based on specific reading criteria (carefully selected indicators that assess certain aspects of the real but not its totality); a set of propositions that logically relate the objects analysed by scientists in the form of bodies of theoretical hypotheses (also called theories) that explain the observed reality; and also a collection of methods of observation, analysis and conceptualisation that aims to maximise the objectivity of its statements and the verification of its processes of evidence production (Paiva, 2014, pp. 5 and 6).

\subsection{Sociological problems}

It follows that Sociology does not deal directly or necessarily with social problems as "lived in society", notwithstanding the possibility of relationships between them in the social context (Santos, 1999), but rather sociological problems that may be considered as a "problem of knowledge about society" (Costa, 1992, p. 116). Contrary to the social problem, often defined "from a partial view, which is influenced in part by its social position" (Almeida, 1995, p. 216; Santos, 1999), being necessary to "impose the existence of the difficulty as an important issue, which always surpasses the boundaries of the group directly affected and becomes legitimate, through a specific formulation process" (Santos, 1999, p. 8), Sociology constructs its specific stance through the corpus of sociological knowledge that "corresponds to a set of translation operations, corresponds to giving visibility within the discipline to certain social problems, also converting them into sociological problems" (Almeida, 1995, p. 18).

According to Santos (1999), the social problem, as a discourse, entails the following features that weaken the coherence of the way to enunciate the social problem:

- The multiplicity of formulations (the discourses are different according to the groups, according to the individuals);

- The variability of the statements from group to group, and even in the case of the same group or individual, according to the circumstances, according to the interlocutors, according to the result to be obtained;

- The non-systematicity, at least if it is understood as the result of a process of deliberate systematisation $[\ldots]$;

- These discourses are also fragmentary, they never cover the whole problems, but rather partial aspects, determined by the particular point of view of the group or the individual, linked to their position in the social structure;

- The performativity: the fundamentally controversial nature of the 'definitions' of what the 'problem' is, or where the 'problem' lies, denounces the performative nature of social discourses on the social problem (pp. 11 and 12).

As maintained by Lenoir (1990), social problems are instituted in all the instruments that participate in the 
current formation of the social world. A social problem is not only the result of the malfunctioning of society, but it presupposes the recognition and legitimation of this problem, which implies socially interested groups in producing a new category of perception of a social situation to act on it, mobilising the society. In this process, as stressed by Ferreira (2007), the state consecration of these social problems that require collective solutions is very relevant. Such solutions are often developed by experts. But for a "problem" to take the form of a social problem, it is not enough to find socially recognized agents as competent to examine their nature and propose acceptable solutions; it will be necessary to impose this "problem" on the public debates and their publicity in a public sphere (Lenoir, 1990). A public sphere arises when certain social forces, which pretend to influence power decisions, constitute a public that makes use of its reason to legitimize some of its demands (Mozzicafreddo 1985: 54).

\subsection{Reflexivity}

It is, thus, the grounded theoretical reflection, for which the use of sociological imagination is central (Mills, 1959), that enables the inevitability of the formulation of a sociological problem, by always entailing a simplification of the complexity of social reality (Almeida, 1995; Costa, 1992). However, it is necessary to bear in mind that sociological problems do not necessarily have to be/originate from social problems (Javeau, 1998), but external influences have always influenced science (Parra Saiani, 2017):

As recently summarized by Foster, Rzhetsky and Evans, many factors have been found to influence a scientist's choice of research problem: past interests and training, serendipitous yet consequential encounters with new collaborators, expertise, or information, institutional context or disciplinary culture; commercial opportunities, pressures, and commercially related policies can change the composition of scientific research and the choices that guide it (p. 91).

In the formulation of the sociological problem, the (real or apparent) social familiarity with social issues that Sociology can study may be an obstacle (Costa, 1992; Javeau, 1998; Santos, 1999). This may be since, in its research process, Sociology can end up dismantling and demystifying everyday preconceived ideas (Elias, 2011). This feature emphasises the need for the rupture, referred to earlier, with preconceived ideas of common sense and social familiarity, separating personal ideas from empirical research during the whole research process (Elias, 2011; Ferreira \& Serpa, 2017; Javeau, 1998; Silva, 1986). This is the modelling idea of "The sociologist as a myth destroyer" (Elias, 2011, p. 53), by calling into question some of the prevailing ideas accepted in society through empirical research.
However, this task of separating value judgments from empirical judgments (Weber) "will never be fully accomplished, inasmuch that, inside and outside groups of specialised scientists, there is always those that convert scientific theories into systems of beliefs" (Elias, 2011, p. 56 ).

The sociologist's perception of reflexivity, in its individual, social and sociological levels, is relevant to help control this process of formulation and study of sociological problems in a sociologically scientific way rigorous and controlled. On the one hand, individual reflexivity:

[...] human agents (i) are competent to analyse the contexts in which they act, (ii) are competent to monitor, in these contexts, their actions and resulting outcomes, (iii) are able to adjust the behaviour in function of that monitoring and (iv) are able to change the contexts following the analysis and monitoring carried out (Pires, 2012, p. 36).

On the other hand, social reflexivity, given that societies "are able to think about themselves and to learn from their experiences and from the knowledge that specialists produce about them" (Costa, 1992, p. 214). Among them, there is, to a certain extent, the incorporation into the society of the results of Sociology, modifying it (Costa, 1992).

Finally, Sociology itself as a reflexive science (Almeida, 1995; Costa, 1992; Ferreira \& Serpa, 2017; Javeau, 1998; Silva, 1986), which permanently self-analyses in its various dimensions, such as the problem construction, methodology, analysis of the results obtained and their implications, by "critically examining what it does (its possibilities, its limits, its procedures) to weigh the conditions under which it does so and the effects of its activity" (Costa, 1992, p. 15).

\section{Conclusions}

Specifically, Sociology, as a "code of reading of the real" (Nunes, 2005, p. 34), so as to make social reality intelligible, can only fulfil this goal through the study of parts selected by the instruments that it uses as a specific form of scientific knowledge, through the formulation of the sociological problem. "Understanding a particular scientific problem means, therefore, first of all knowing the difficulty that causes it, and the context that is internal (theoretical, technical) and external (historical, social) to the scientific environment in which it is produced" (Santos, 1999, p. 12).

This study acknowledges the importance of clearly distinguishing social problem from sociological problem in scientific activity, as distinct dimensions. However, this is not an impediment for the results and conclusions obtained through sociological knowledge to be applied in the effort to solve what may be considered, in the perception of some 
individuals, as a social problem.

Therefore, the process of producing any problem must be analysed sociologically as a social phenomenon (analysis of the interests of all actors and social relations that the process implies), and as a discursive and conceptual phenomenon (Santos, 1999). Sociology makes us discover this particular form of interest that is disinterest for interest (Bourdieu, 1994).

\section{Author Contributions}

All authors contributed equally to this article.

\section{Funding}

University of Azores, Interdisciplinary Centre of Social Sciences-CICS.UAc/CICS.NOVA.UAc, UID/SOC/04647/2013, with the financial support of the FCT/MEC through national funds and when applicable co-financing from the FEDER under the PT2020 Partnership Agreement.

\section{Conflicts of Interest}

The authors declare no conflict of interest.

\section{Acknowledgments}

The authors acknowledge the comments and suggestion by two anonymous reviewers.

\section{REFERENCES}

[1] Almeida, J. F. (1995). Introdução à Sociologia [Introduction to Sociology]. Lisboa: Universidade Aberta.

[2] Almeida, J. F., \& Pinto, J. M. (1986). Da teoria à investigação empírica, problemas metodológicos [From theory to empirical research, methodological problems]. In A. S. Silva \& J. M. Pinto (Orgs.), Metodologia das ciências sociais [Methodology of social sciences] (8th ed.) (pp. 55-78). Porto: Edições Afrontamento.

[3] $\mathrm{Au}, \mathrm{A}$. (2017). Sociology and science: The making of a social scientific method. The American Sociologist, 49(1), 98-115. DOI: 10.1007/s12108-017-9348-y.

[4] Bourdieu, P. (1994). Raisons pratiques: sur la théorie de l'action. Paris: Seuil.

[5] Cherkaoui, M. (1990). Socialização [Socialisation]. In R. Boudon, P. Besnard, M. Cherkaoui, \& B.-P. Lécuyer (Dirs.), Dicionário de Sociologia [Dictionary of Sociology] (p. 227). Lisboa: Publicações Dom Quixote.
[6] Costa, A. F. (1992). Sociologia - O que é? [Sociology What is it?] Lisboa: Difusão Cultural.

[7] Durkheim, E. (1895/1998). As regras do método sociológico [The rules of sociological method]. Lisboa: Editorial Presença.

[8] Elias, N. (2011). Introdução à Sociologia [Introduction to Sociology]. Lisboa: Edições 70.

[9] Ferreira, C. M. (2007). A medicalização dos sanatórios populares. Desafios e formas de um processo social [The medicalisation of popular sanatoria. Challenges and forms of a social process]. Lisboa: Faculdade de Ciências Sociais e Humanas da Universidade Nova de Lisboa. Ph.D. Thesis.

[10] Ferreira, C. M., \& Serpa, S. (2017). Essay challenges in the teaching of Sociology in higher education. Contributions to a discussion. Societies, 7(30), 1-11. DOI: $10.3390 / \operatorname{soc} 7040030$.

[11] Javeau, C. (1998). Lições de Sociologia [Lessons of Sociology]. Oeiras: Celta Editora.

[12] Lenoir, R. (1990). Objet sociologique et problème social [Sociological object and social problem]. In P. Champagne, R. Lenoir, D. Merllié, \& L. Pinto, Initiation à la Pratique Sociologique [Initiation to Sociological Practice] (pp. 57-100). Paris: Dunod.

[13] Mills, C. W. (1959). The sociological imagination. Oxford: Oxford University Press.

[14] Mora, M. A. (2015). Algunos problemas de fundamentación y justificación sociológica: Apuntes en el marco del debate teórico de la sociología contemporánea [Some problems of sociological justification and foundation: Notes on the theoretical debate of contemporary sociology]. Revista ABRA, 35(50). DOI: 10.15359/abra.35-50.1.

[15] Mozzicafreddo, J. (1985). Liberalismo, política e democracia [Liberalism, politics and democracy]. Revista de Comunicação e Linguagens, n 2, Porto: Edições Afrontamento.

[16] Nunes, A. S. (2005). Questões preliminares sobre as ciências sociais [Preliminary issues on social sciences] (13rd ed.). Barcarena: Editorial Presença.

[17] Paiva, A. (2014). Pensamento sociológico. Uma introdução didática às teorias clássicas [Sociological thinking. A didactic introduction to classical theories]. Lisboa: PACTOR: Edições de Ciências Sociais, Forenses e da Educação.

[18] Parra Saiani, P. (2017). Doing sociology in the age of "evidence-based research": Scientific epistemology versus political dominance. The American Sociologist, 49(1), 80-97. DOI: $10.1007 / \mathrm{s} 12108-017-9358-9$.

[19] Pires, R. P. (2012). O problema da ordem [The problem of order]. Sociologia, Problemas e Práticas, 69, 31-45. DOI: 10.7458/spp201269785.

[20] Santos, J. R. (1999). A propósito das noções de "problema social" e "problema sociológico" [On the notions of "social problem" and "sociological problem"]. In Homenagem ao Professor Augusto da Silva [Tribute to Professor Augusto da Silva] (pp. 417-441). Évora: Universidade de Évora, Departament of Sociology, 


\section{CIDEHUS.}

[21] Serpa, S. (2018). A reflection on Sociology of Education. International Journal of Social Science Studies, 6(3), 33-39. DOI: 10.11114/ijsss.v6i3.3013.

[22] Silva, A. S. (1986). A ruptura com o senso comum nas ciências sociais [The rupture with common sense in social sciences]. In A. S. Silva \& J. M. Pinto (Orgs.), Metodologia das ciências sociais [Methodology of social sciences] (8th ed.) (pp. 29-53). Porto: Edições Afrontamento. 